\title{
National Survey of Pharmacy Practice at MOH Hospitals in Saudi Arabia 2016-2017: Pharmacy Management and Resource
}

\author{
Yousef Ahmed Alomi*1, Saeed Jamaan Alghamdi², Radi Abdullah Alattyh ${ }^{2}$ \\ ${ }^{1}$ The Past General Manager of General Administration of Pharmaceutical Care and Head, National Clinical pharmacy, and \\ pharmacy practice and Pharmacy R and D Administration, Ministry of Health, Riyadh, KSA. \\ ${ }^{2}$ Department of Pharmacy Practice, College of Pharmacy, King Khalid University, Abha, SAUDI ARABIA. \\ ${ }^{3}$ Department of Pharmacy, King Saud Medical City, Ministry of Health, P.O.BOX 100, Riyadh 11392, Riyadh, SAUDI ARABIA. \\ ${ }^{4}$ Department of Pharmacy, Security Forces Hospital, Riyadh, SAUDI ARABIA.
}

Received: 12 October 2017;

Accepted: 27 December 2017

*Correspondence to:

Dr. Yousef Ahmed Alomi,

${ }^{1}$ The Past General Manager of General Administration of Pharmaceutical Care and Head, National Clinical pharmacy, and pharmacy practice and Pharmacy $R \& D$ Administration, Ministry of Health, Riyadh, KSA ${ }^{2}$ General Administration of Pharmaceutical Care, Ministry of Health, Riyadh, Saudi Arabia Email:yalomi@gmail.com

Copyright: (c) the author(s),publisher and licensee Indian Academy of Pharmacists. This is an open-access article distributed under the terms of the Creative Commons Attribution Non-Commercial License, which permits unrestricted non-commercial use, distribution, and reproduction in any medium, provided the original work is properly cited.

\begin{abstract}
Objective: To explore the National Survey of Pharmacy Practice at MOH hospitals in Saudi Arabia 20162017: Pharmacy Management and resources. Methods: It is a 4-months cross-sectional National Survey of Pharmacy Practice at $\mathrm{MOH}$ hospitals in Saudi Arabia. The study consisted of two parts; the demographic information and the second part contained eighty-five questions divided into nine domains drove from American Society of Health-System Pharmacists (ASHP) and Saudi Pharmaceutical Society (SPS) survey, the international standard of Joint Commission of Hospital Accreditation, and the local standards of Saudi Center of healthcare accreditation. An electronic questionnaire was distributed to one hundred eighty-five directors of pharmacies at $\mathrm{MOH}$ hospitals. The study discussed and analyzed National Survey of Pharmacy Practice at MOH hospitals in Saudi Arabia: Pharmacy Management and resources. All analysis was done through survey monkey system. Results: The survey questionnaire was distributed to 185 hospitals, the rate of reply, was $105(56.75 \%)$. The most of the hospital pharmacies provide their services to the adult emergency $(91.18 \%)$, medical $(90.82 \%)$, and surgical patients $(87.76 \%)$. The highest number of prescriptions annually was adults emergency $(5,094,000)$, Pediatrics emergency $(3,357,000)$ and medical services $(2,340,000)$. The majority of pharmacy services consisted of outpatient pharmacy $88(92.63 \%)$, inpatient pharmacy $81(82.65 \% \%)$, pharmacy store 77 (77.00\%), and emergency pharmacy 63(68.48\%). The seldom finding of pharmacy services were satellite pharmacy $7(8.33 \%)$, clinical pharmacy $7(10.47 \%)$, followed by repackaging system 27 (31.76\%) and Intravenous admixture servicers 29(32.22\%). The total number prescriptions dispensed were $(32,643,000)$ annually with $(25,110.01)$ prescriptions per hospital per year. The total numbers of pharmacists were (953), and pharmacy technicians were (1251). The average space size of hospital pharmacy was $\left(113.98 \mathrm{~m}^{2}\right)$ with the highest space, outpatient pharmacy $\left(32.16 \mathrm{~m}^{2}\right)$ followed by inpatient pharmacy $\left(24 \mathrm{~m}^{2}\right)$ and pharmacy store $\left(22.42 \mathrm{~m}^{2}\right)$. Conclusion: Most of the hospital pharmacies missed some essential of pharmacy practice with emphasis on Human Resources and clinical pharmacy services. Implementing $\mathrm{MOH}$ pharmacy strategic plan with close monitoring is required for all hospitals in Saudi Arabia.
\end{abstract}

Key word: Pharmacy management, Human resources, Ministry of Health, Saudi Arabia.

\section{INTRODUCTION}

The Hospital pharmacy establishment needs minimum standard. The American society of hospital pharmacy published minimum standard of hospital pharmacy consisted of several elements for instance but not limited to the leadership, drug distribution and control Human Resources, education, training, and pharmacy research..$^{[1]}$ The ASHP conducted a survey at every certain period to measure the pharmacy services across united states of America over past years until now. ${ }^{[2,3,4,5,6,7]}$ Recently the ASHP is focusing on six domain like prescribing, transcending, dispensing, Administration, drug monitoring, and patient education. ${ }^{[2,3]}$ Every year surveyed about two domains. The Saudi Pharmaceutical Society with the cooperation of ASHP before several years did a survey in Kingdom of Saudi Arabia with same six domains..$^{\left[{ }^{8,910]}\right.}$ However, the number of hospitals was few and not investigated Ministry of health hospitals. Also, it was hard to find hospital pharmacy practice in Gulf and Middle East counties. The objective of this study is to explore the National Survey of Pharmacy Practice at $\mathrm{MOH}$ hospitals in Saudi Arabia, with emphasis on the pharmacy management and resources.

\section{METHODS}

It is a 4-months cross-sectional National Survey of Pharmacy Practice at $\mathrm{MOH}$ hospitals in Saudi Arabia. The study consisted of two parts; the demographic information and the second part contained eighty-five questions divided into nine domains drove from American Society of HealthSystem Pharmacists (ASHP) and Saudi Pharmaceutical Society (SPS) survey, the international standard of Joint Commission of Hospital Accreditation in addition to the local standards of Saudi Center of healthcare accreditation. $[3,5,8,9,10,11,12]$ The parts were pharmacy management and resources, prescribing and medication control, preparation of medications and dispensing, computerized and pharmacy technology, clinical pharmacy services, drug 
Table 1: Demographic responder qualifications information.

\begin{tabular}{|c|c|c|c|c|c|}
\hline & Response N & Response \% & & & \\
\hline Nationality & Response N & Response \% & No. of hospital Licensed Beds & Response N & Response \% \\
\hline Saudi & 101 & $96.2 \%$ & $<50$ & 32 & $30.5 \%$ \\
\hline Non-Saudi & 4 & $3.8 \%$ & $50-99$ & 21 & $20.0 \%$ \\
\hline Answered question & 105 & & $100-199$ & 16 & $15.2 \%$ \\
\hline Skipped question & 0 & & 200-299 & 19 & $18.1 \%$ \\
\hline Age & Response N & Response \% & 300-399 & 10 & $9.5 \%$ \\
\hline $18-40$ & 99 & $94.29 \%$ & $400-499$ & 6 & $5.7 \%$ \\
\hline $40-56$ & 5 & $4.76 \%$ & $=$ or $>600$ & 1 & $1.0 \%$ \\
\hline $65+$ & 1 & $0.95 \%$ & Medical City & 0 & $0.0 \%$ \\
\hline Answered question & 105 & & Answered question & 105 & \\
\hline Skipped question & 0 & & Skipped question & 0 & \\
\hline Aacademic qulifications & Response N & Response \% & Board of Pharmaceutical Specialty & Response $\mathbf{N}$ & Response \% \\
\hline Diploma Pharmacy & 28 & $26.67 \%$ & Board Certified Ambulatory Care Pharmacist (BCACP) & 1 & $1.0 \%$ \\
\hline Bsc. Pharm & 59 & $56.19 \%$ & Board Certified Critical Care Pharmacist (BCCCP) & 1 & $1.0 \%$ \\
\hline M.S & 10 & $9.52 \%$ & Board Certified Nuclear Pharmacist (BCNP) & 0 & $0.0 \%$ \\
\hline Msc. Clinical Pharmacy & 0 & $0.00 \%$ & Board Certified Nutrition Support Pharmacist (BCNSP) & 0 & $0.0 \%$ \\
\hline Pharm.D. & 10 & $9.52 \%$ & Board Certified Oncology Pharmacist (BCOP) & 0 & $0.0 \%$ \\
\hline Ph.D & 2 & $1.90 \%$ & Board Certified Pediatric Pharmacy Specialist (BCPPS) & 0 & $0.0 \%$ \\
\hline MBA & 1 & $0.95 \%$ & Board Certified Pharmacotherapy Specialists (BCPS) & 1 & $1.0 \%$ \\
\hline Pharmacy Residency Two years (R1) & 2 & $1.90 \%$ & Board Certified Psychiatric Pharmacist (BCPP) & 0 & $0.0 \%$ \\
\hline Pharmacy Residency one year (R2) & 0 & $0.00 \%$ & Non & 95 & $96.9 \%$ \\
\hline Fellowship & 1 & $0.95 \%$ & Answered question & 98 & \\
\hline Other (please specify) & 2 & $1.90 \%$ & Skipped question & 7 & \\
\hline $\begin{array}{l}\text { answered question: } 105 \text { and skipped } \\
\text { question: } 0\end{array}$ & & & & & \\
\hline
\end{tabular}

\begin{tabular}{|c|c|c|c|c|c|c|c|c|c|c|}
\hline \multicolumn{11}{|c|}{ Hospital accreditation } \\
\hline \multirow[b]{2}{*}{ Answer Options } & \multicolumn{8}{|c|}{ Hospital beds } & \multirow[b]{2}{*}{ Response \% } & \multirow[b]{2}{*}{ Response N } \\
\hline & $<50$ & $50-99$ & $100-199$ & $200-299$ & $300-399$ & $400-499$ & $=$ or $>600$ & $\begin{array}{l}\text { Medical } \\
\text { City }\end{array}$ & & \\
\hline CIBAHI & 12 & 6 & 7 & 14 & 8 & 3 & 1 & 0 & $48.6 \%$ & 51 \\
\hline Joint CommotionUSA & 1 & 0 & 1 & 3 & 2 & 2 & 1 & 0 & $9.5 \%$ & 10 \\
\hline Canada & 0 & 0 & 1 & 0 & 0 & 0 & 0 & 0 & $1.0 \%$ & 1 \\
\hline Saudi Council & 11 & 10 & 4 & 3 & 1 & 1 & 0 & 0 & $28.6 \%$ & 30 \\
\hline Other (please specify) & 9 & 5 & 5 & 3 & 1 & 2 & 0 & 0 & $23.8 \%$ & 25 \\
\hline \multicolumn{11}{|c|}{ answered question: 105 and skipped question: 0} \\
\hline \multicolumn{11}{|c|}{ Health insurance coverage } \\
\hline & \multicolumn{8}{|c|}{ Hospital Beds } & & \\
\hline Answer Options & $<50$ & $50-99$ & $100-199$ & 200-299 & $300-399$ & $400-499$ & $=$ or $>600$ & $\begin{array}{l}\text { Medical } \\
\text { City }\end{array}$ & Response \% & Response N \\
\hline Non & 25 & 14 & 11 & 8 & 5 & 4 & 0 & 0 & $63.8 \%$ & 67 \\
\hline$<25 \%$ & 4 & 3 & 4 & 7 & 2 & 2 & 1 & 0 & $21.9 \%$ & 23 \\
\hline $25-49 \%$ & 1 & 3 & 0 & 3 & 2 & 0 & 0 & 0 & $8.6 \%$ & 9 \\
\hline $50-74 \%$ & 1 & 0 & 0 & 0 & 0 & 0 & 0 & 0 & $1.0 \%$ & 1 \\
\hline $75-100 \%$ of our patients. & 1 & 1 & 1 & 1 & 1 & 0 & 0 & 0 & $4.8 \%$ & 5 \\
\hline
\end{tabular}


monitoring and patient's education, pharmacy inventory control and stock management, Pharmacy education and training, and pharmacy total quality management. The 5-point Likert response scale system with closed and ended questions was used. An electronic questionnaire distributed to the one hundred eighty-five directors of pharmacies at MOH hospitals. The follow-up was taken by the email and telephone at every one-two week. All primary care centers, pharmacy administration at $\mathrm{MOH}$ or regions excluded from the study. The study discussed and analyzed National Survey of Pharmacy Practice at MOH hospitals in Saudi Arabia: Pharmacy Management and resources. All analyses are done through survey monkey system.

\section{RESULTS}

The survey questionnaire was distributed to 185 hospitals, the rate of reply, was $105(56.75 \%)$ hospitals. Of that $30.5 \%$ of (< 50 beds) hospitals, $20.0 \%$ of (50-99 beds) hospitals, $15.2 \%$ of (100-199 beds) hospitals, $18.1 \%$ of (200-299 beds) hospitals, $16.5 \%$ of (= or $>300$ beds) hospitals. OfF those, fifty-one $(48.57 \%)$ hospitals accredited by CIBAHI, $30(28.57 \%)$ hospitals accredited by Saudi Commission of Health Specialties, and ten $(9.52 \%)$ hospitals only accredited by Joint Commission. While twenty-two $(20.95 \%)$ hospitals were not accredited by any organizations and 67 (63.8\%) patient were not covered by any health insurance. The majority age of responders was (18-40) years $99(94.29 \%)$ while the nationalities were Saudi 101(96.2\%) and Non-Saudi 4 (3.8\%). Most of the responders had BSc Pharm 59 (56.19\%) and diploma of pharmacy 28 (26.67\%) while 95 (96.9\%) none certified of Board of Pharmaceutical Specialties. Most of the responders had pharmacy experiences 4-6 years $(72.34 \%)$, while $(40.00 \%)$ of responders had $1-3$ years pharmacy administration, and $(73.33 \%)$ had no experiences in clinical pharmacy as explored in Table 1, Table 2 , and Table 3 . The most of the hospital pharmacies provide their services to the adult emergency (91.18\%), medical $(90.82 \%)$, and surgical patients $(87.76 \%)$. While the highest number of prescription annually was adults emergency $(5,094,000)$, Pediatrics emergency $(3,357,000)$ and medical services $(2,340,000)$ as explored in Table 4 and Table 5. The majority of pharmacy services consisted of outpatient pharmacy 88 (92.63\%), inpatient pharmacy $81(82.65 \% \%)$, pharmacy store $77(77.00 \%)$, and emergency pharmacy $63(68.48 \%)$. The seldom finding of pharmacy services were satellite pharmacy $7(8.33 \%)$, clinical pharmacy $7(10.47 \%)$, followed by repackaging system 27 (31.76\%) and Intravenous admixture servicers $29(32.22 \%)$. The total number of prescriptions dispensed $(32,643,000)$ annually with $(25,110.01)$ prescriptions per hospital per year as explored in Table 6 and Table 7. The total numbers of pharmacists were (953), and pharmacy technicians were (1251). The average space size of hospital pharmacy was $\left(113.98 \mathrm{~m}^{2}\right)$ with the highest space, outpatient pharmacy $\left(32.16 \mathrm{~m}^{2}\right)$ followed by inpatient pharmacy $\left(24 \mathrm{~m}^{2}\right)$ and pharmacy store $\left(22.42 \mathrm{~m}^{2}\right)$ as explored in Table 8 , and Table 9.

\section{DISCUSSION}

The general administration of pharmaceutical care updated all hospital pharmacies related issues based on the pharmacy strategic plan that is approved by $\mathrm{MOH}{ }^{[13]}$. They updated hospital pharmacy skeleton, new vision and mission along with policy and procedures. The pharmacy workforce updated with five times folds incremental. ${ }^{[14]}$ Several pharmacy administration programs implemented for instance pharmacist job satisfaction, patient pharmacy services satisfaction, pharmacist competencies, and pharmacy patient bill of rights. ${ }^{[15,16,17]}$ A new system for incremental salary for directors and supervisors of hospital pharmacy department included directors of pharmacy, inpatient supervisor, outpatient supervisor and drug information center director. Several educational courses conducted about pharmacy leadership skills for directors of hospital pharmacy. The pharmacy administration followed the ASHP best practice standards and Saudi Center of Healthcare Institution Accreditation and required from all hospital pharmacies to get accreditation from them. ${ }^{[11]}$ Task force committee on Pharmacy quality management was implemented. The committee conducted several courses to train pharmacy staff about quality management. The authors investigated the strengths and weakness of hospital pharmacy practice with emphasis on pharmacy management and resources. The finding showed the most of the hospital pharmacies provide their services to the adult emergency medical, and surgical patients; the results are usually because hospital had that department with emphasis on the patient at an emergency department and had more visitors than admission patients as reported by $\mathrm{MOH}$ statistical yearbook. ${ }^{[18]}$ The majority of four pharmacy services included at hospitals were an outpatient pharmacy, inpatient pharmacy, pharmacy store, and emergency pharmacy that are present at most of the hospitals. The hospitals still apply the old role of the pharmacist as the distribution without the complete concept of pharmaceutical resemble what reported by Alsultan ME et al., as drug distribution centered model. ${ }^{[9]}$ It was challenging to find pharmacy services were satellite pharmacy or clinical pharmacy because the role of clinical specialist centered made by the pharmacist is low as reported by Alsultan ME et al.(9). The finding of presenting of Intravenous admixture services was low as reported by Alsultan ME et al. ${ }^{[9]}$ The total numbers of pharmacists and pharmacy technicians were less than what reported by Pedersen CA et al., and there was a high shortage of pharmacy staff and less than $\mathrm{MOH}$ hospital pharmacy staff requirement standard. ${ }^{[2,14]}$ The finding of space size of hospital pharmacy as general or for each department, was not sufficient as compared with $\mathrm{MOH}$ pactice standard. This finding could not compare with previous studies because of unavailability of the data.

\section{CONCLUSION}

The primary element of pharmacy services not existed at most of $\mathrm{MOH}$ hospitals, includes pharmacy human resources, satellite pharmacy missed clinical pharmacy, and shortages of Intravenous services. The clinical role of pharmacist missed to the majority of department included emergency, medical and surgical department. Targeting to implement general update administration of pharmaceutical care planning is highly recommended at $\mathrm{MOH}$ hospitals in Kingdom of Saudi Arabia.

\section{ACKNOWLEDGEMENT}

None

Table 3: The responder experiences information.

\begin{tabular}{|c|c|c|c|c|c|c|c|}
\hline Years of experience & $\begin{array}{c}\text { Pharmacy } \\
\text { Practice }\end{array}$ & Percent & $\begin{array}{l}\text { Clinical } \\
\text { Pharmacy }\end{array}$ & Percent & $\begin{array}{c}\text { Pharmacy } \\
\text { Administration }\end{array}$ & Percent & Response N \\
\hline 0 & 2 & $13.33 \%$ & 11 & $73.33 \%$ & 2 & $13.33 \%$ & 15 \\
\hline$<1$ year & 12 & $38.71 \%$ & 8 & $25.81 \%$ & 11 & $35.48 \%$ & 31 \\
\hline $1-3$ & 23 & $57.50 \%$ & 1 & $2.50 \%$ & 16 & $40.00 \%$ & 40 \\
\hline $4-6$ & 34 & $72.34 \%$ & 1 & $2.13 \%$ & 12 & $25.53 \%$ & 47 \\
\hline$>6$ years & 43 & $84.31 \%$ & 0 & $0.00 \%$ & 8 & $15.69 \%$ & 51 \\
\hline $\begin{array}{l}\text { answered question: } 105 \text { and } \\
\text { skipped question: } 0\end{array}$ & & & & & & & \\
\hline
\end{tabular}




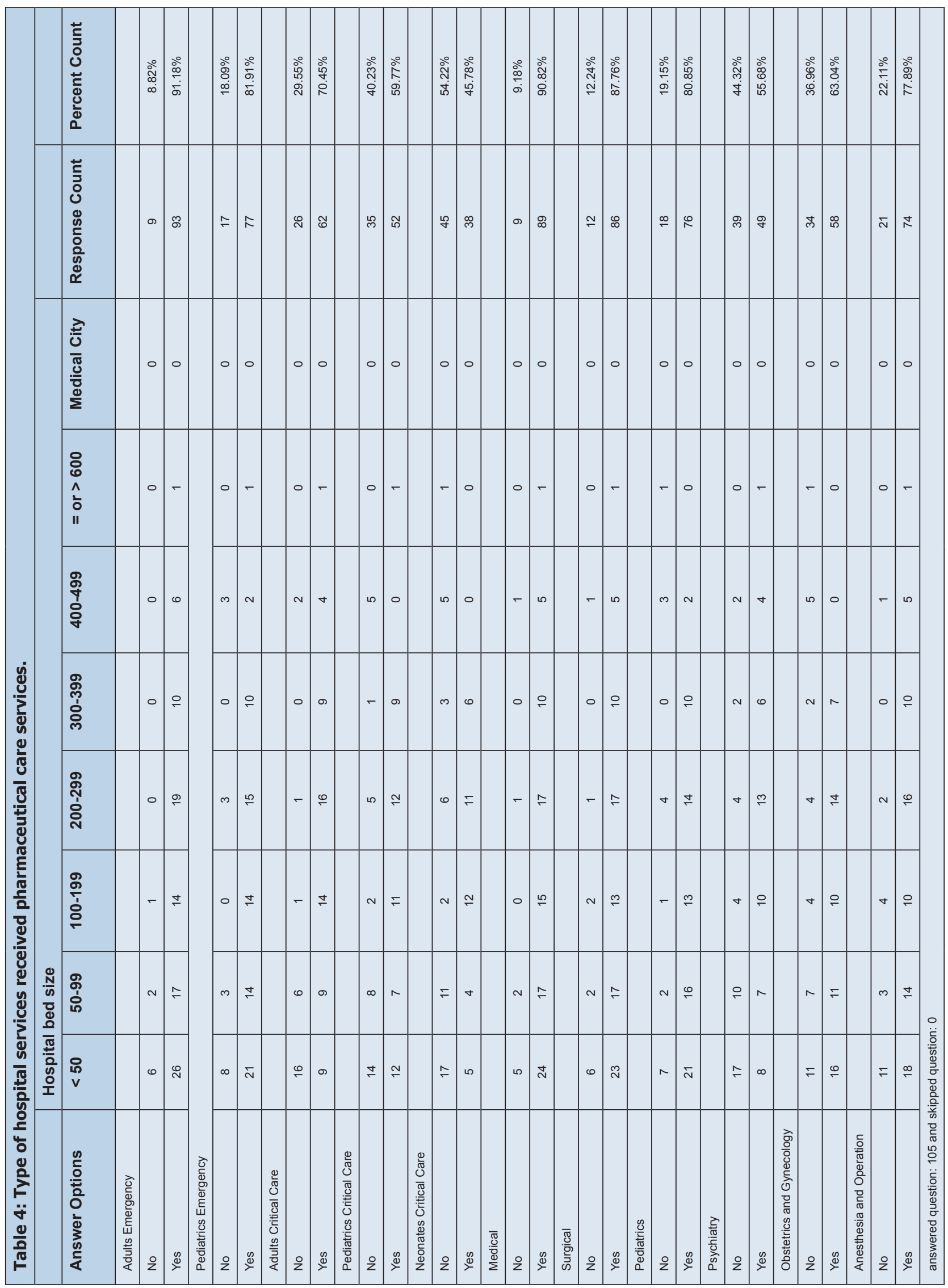




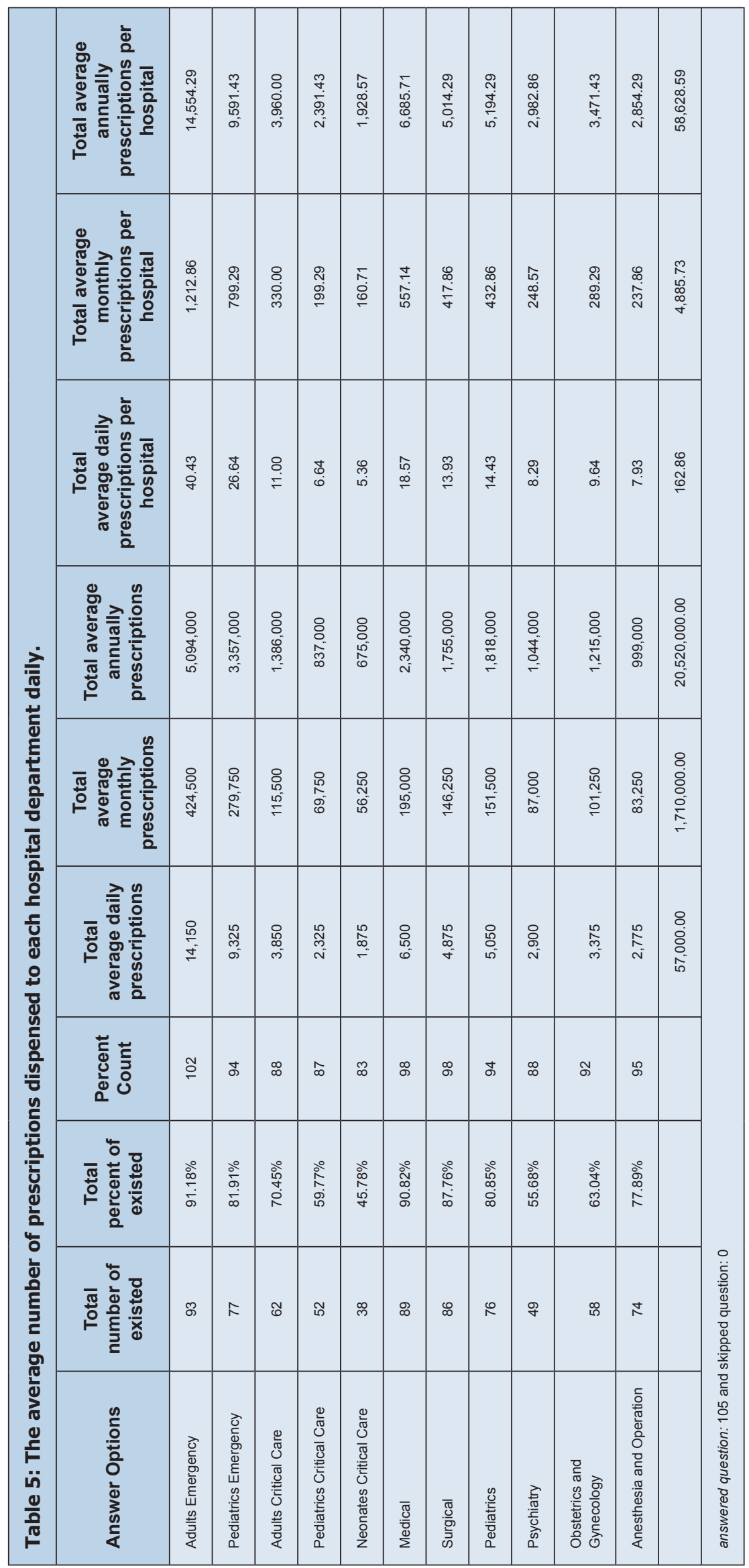


Alomi et al.:Pharmacy Management and Resource

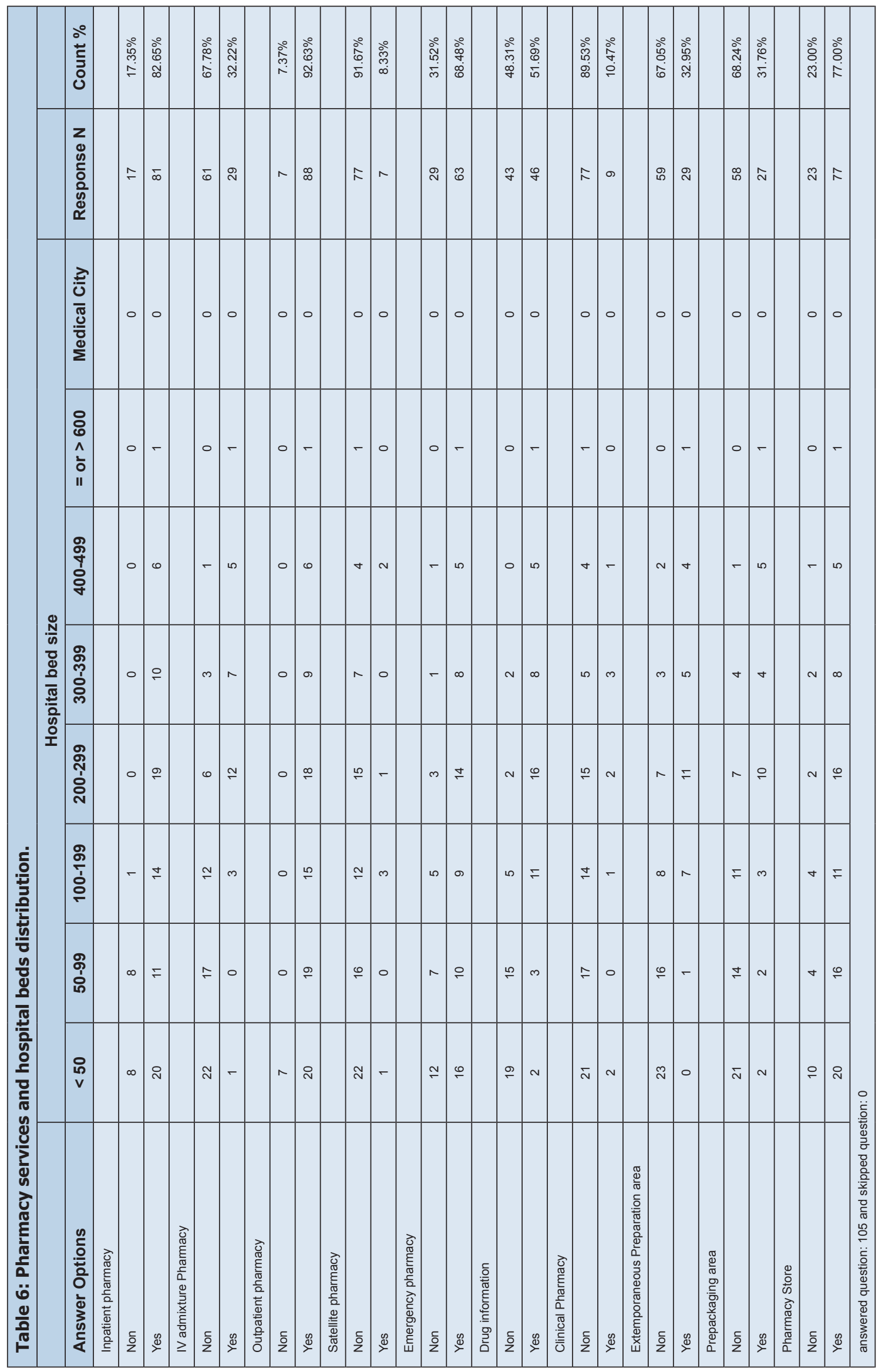




\begin{tabular}{|c|c|c|c|c|c|c|c|c|c|c|c|c|}
\hline & 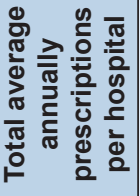 & 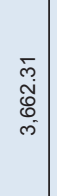 & 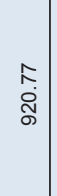 & $\begin{array}{l}\infty \\
0 \\
0 \\
\stackrel{0}{i} \\
\end{array}$ & \begin{tabular}{l}
$\bar{\rho}$ \\
\multirow{N}{J}{}
\end{tabular} & 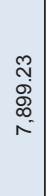 & 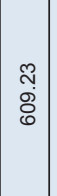 & $\begin{array}{l}0 \\
+ \\
0 \\
o \\
\sigma\end{array}$ & $\left|\begin{array}{c}0 \\
0 \\
\dot{d} \\
i\end{array}\right|$ & 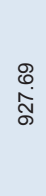 & 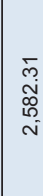 & 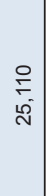 \\
\hline & 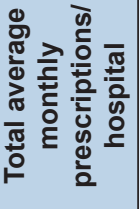 & 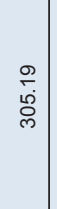 & $\begin{array}{l}\mathfrak{m} \\
\hat{i} \\
i\end{array}$ & 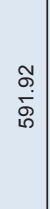 & $\begin{array}{l}\stackrel{9}{\dot{b}} \\
\dot{w}\end{array}$ & $\begin{array}{l}\hat{N} \\
0 \\
0 \\
0\end{array}$ & $\mid \begin{array}{l}\hat{1} \\
\dot{0} \\
\dot{0}\end{array}$ & 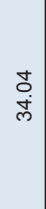 & $\mid$\begin{tabular}{c}
$\infty$ \\
$\infty$ \\
\multirow{\sigma}{*}{}
\end{tabular} & $\stackrel{\bar{m}}{\stackrel{n}{R}}$ & $\frac{\vec{\sigma}}{\frac{\rho}{N}}$ & $\begin{array}{l}\tilde{N} \\
\stackrel{N}{*}\end{array}$ \\
\hline & 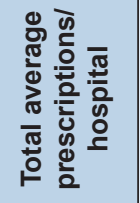 & $\begin{array}{l}\hat{f} \\
\stackrel{0}{0}\end{array}$ & $\begin{array}{l}\stackrel{0}{0} \\
\stackrel{\sim}{i}\end{array}$ & $\begin{array}{l}\tilde{N} \\
\stackrel{\tilde{\sigma}}{\sigma}\end{array}$ & $\stackrel{f}{\rightleftharpoons}$ & $\begin{array}{l}\frac{d}{\sigma} \\
\dot{N}\end{array}$ & $\mid \stackrel{\leftrightarrow}{-}$ & $\stackrel{m}{\rightleftarrows}$ & $\stackrel{\leftrightarrow}{\stackrel{\leftrightarrow}{\leftarrow}}$ & 怘 & 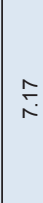 & $\therefore$ \\
\hline & 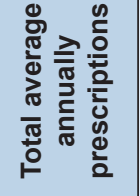 & 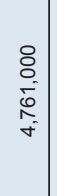 & 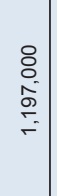 & 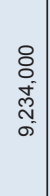 & $\begin{array}{l}0 \\
8 \\
o \\
o \\
0 \\
0\end{array}$ & $\begin{array}{l}0 \\
0 \\
0 \\
0 \\
0 \\
0 \\
0\end{array}$ & 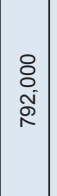 & 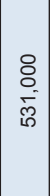 & 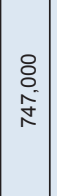 & $\begin{array}{l}\stackrel{8}{0} \\
\stackrel{0}{0} \\
\stackrel{0}{-}\end{array}$ & 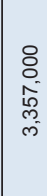 & 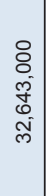 \\
\hline 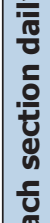 & 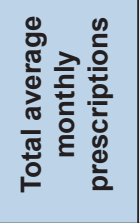 & $\begin{array}{l}\text { p. } \\
0 \\
o \\
0 \\
\end{array}$ & $\begin{array}{l}0 \\
0 \\
o \\
o\end{array}$ & $\begin{array}{l}8 \\
0 \\
0 \\
o 8 \\
1\end{array}$ & $\begin{array}{l}0 \\
h \\
\dot{q} \\
\dot{b}\end{array}$ & $\begin{array}{l}0 \\
0 \\
0 \\
0 \\
\infty\end{array}$ & $\mid \begin{array}{l}0 \\
: \\
0 \\
0\end{array}$ & $\mid \begin{array}{c}0 \\
\stackrel{N}{0} \\
\dot{J}\end{array}$ & 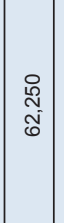 & $\mid \begin{array}{l}0 \\
0 \\
0 \\
0 \\
0\end{array}$ & \begin{tabular}{|l}
0 \\
0 \\
$o$ \\
$o$ \\
\end{tabular} & 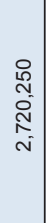 \\
\hline 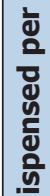 & 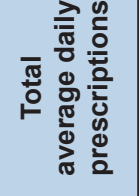 & $\left|\begin{array}{c}\stackrel{\sim}{N} \\
\widetilde{\sim} \\
\end{array}\right|$ & 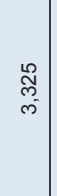 & $\begin{array}{l}0 \\
0 \\
c \\
\stackrel{0}{0}\end{array}$ & $\stackrel{\stackrel{\sim}{\sim}}{\stackrel{\leftrightarrow}{\leftarrow}}$ & $\begin{array}{l}\omega \\
\sim \\
\infty \\
N \\
N\end{array}$ & $\left|\begin{array}{l}8 \\
\underset{i}{N}\end{array}\right|$ & 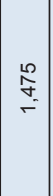 & $\left|\begin{array}{l}0 \\
\stackrel{2}{ } \\
i\end{array}\right|$ & \begin{tabular}{|l|}
0 \\
$\stackrel{0}{m}$ \\
$\tilde{m}$
\end{tabular} & \begin{tabular}{|l} 
బ్ల \\
$\sigma$ \\
$\sigma$
\end{tabular} & $\begin{array}{l}\qquad \\
0 \\
0 \\
8 \\
8\end{array}$ \\
\hline 号 & 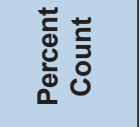 & 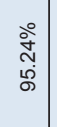 & $\begin{array}{c}\stackrel{\circ}{\stackrel{े}{े}} \\
\dot{\omega}\end{array}$ & 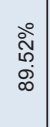 & $\begin{array}{c}\stackrel{\circ}{0} \\
\dot{y} \\
\dot{0}\end{array}$ & 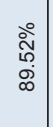 & 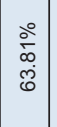 & 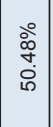 & $\mid \begin{array}{c}\stackrel{\circ}{\circ} \\
\stackrel{\circ}{6} \\
\leftrightarrow\end{array}$ & 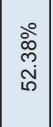 & 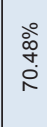 & \\
\hline 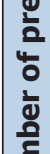 & 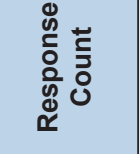 & $\stackrel{\circ}{\circ}$ & 8 & \% & F & ठ & $\hat{0}$ & 足 & 吕 & 吕 & I & \\
\hline 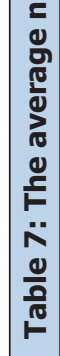 & 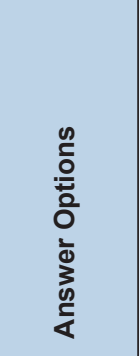 & 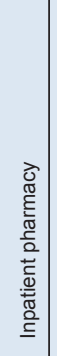 & 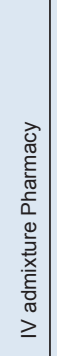 & 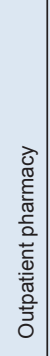 & 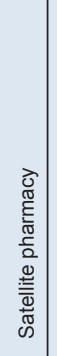 & 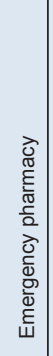 & 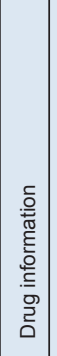 & 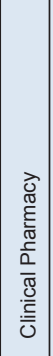 & 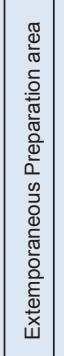 & 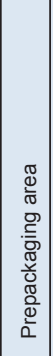 & 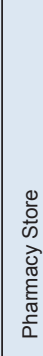 & \\
\hline
\end{tabular}

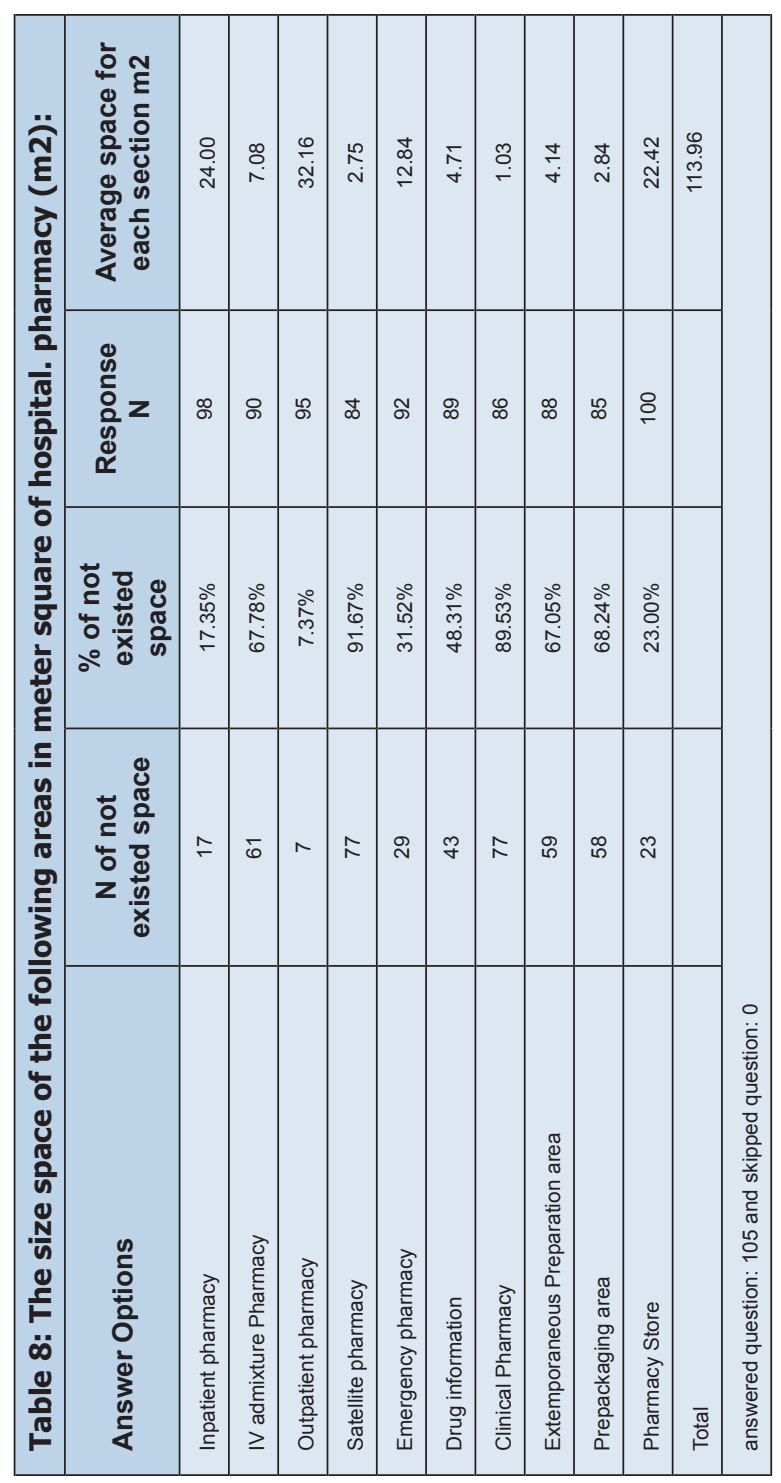




\begin{tabular}{|c|c|c|c|c|c|c|c|c|c|c|}
\hline Answer Options & 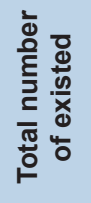 & 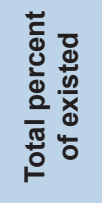 & 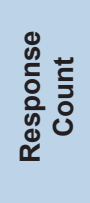 & 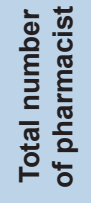 & 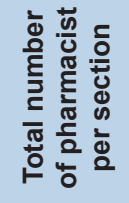 & 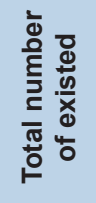 & 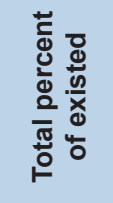 & 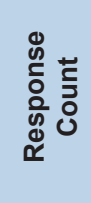 & 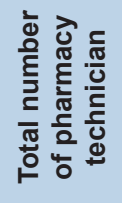 & 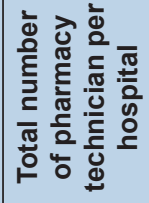 \\
\hline Inpatient pharmacy & 79 & $80.61 \%$ & 98 & 251 & 3.18 & 77 & $24.84 \%$ & 97 & 310 & 4.03 \\
\hline IV admixture Pharmacy & 23 & $27.71 \%$ & 83 & 67 & 2.91 & 16 & $24.62 \%$ & 83 & 65 & 4.06 \\
\hline Outpatient pharmacy & 86 & $89.58 \%$ & 96 & 279 & 3.24 & 84 & $23.08 \%$ & 96 & 364 & 4.33 \\
\hline Satellite pharmacy & 1 & $1.30 \%$ & 77 & 1 & 1.00 & 1 & $100.00 \%$ & 76 & 1 & 1.00 \\
\hline Emergency pharmacy & 52 & $58.43 \%$ & 89 & 136 & 2.62 & 69 & $24.13 \%$ & 94 & 286 & 4.14 \\
\hline Drug information & 46 & $52.27 \%$ & 88 & 61 & 1.33 & 7 & $87.50 \%$ & 85 & 8 & 1.14 \\
\hline Clinical Pharmacy & 16 & $19.51 \%$ & 82 & 32 & 2.00 & 5 & $62.50 \%$ & 84 & 8 & 1.60 \\
\hline Extemporaneous Preparation area & 18 & $21.69 \%$ & 83 & 22 & 1.22 & 22 & $73.33 \%$ & 85 & 30 & 1.36 \\
\hline Prepackaging area & 16 & $19.75 \%$ & 81 & 32 & 2.00 & 19 & $57.58 \%$ & 86 & 33 & 1.74 \\
\hline Pharmacy Store & 36 & $40.45 \%$ & 89 & 72 & 2.00 & 61 & $41.78 \%$ & 93 & 146 & 2.39 \\
\hline Total & & & & 953 & 21.5 & & & & 1251 & 25.79 \\
\hline
\end{tabular}

\section{CONFLICT OF INTEREST}

None

\section{SOURCE OF SUPPORT}

None

\section{ABBREVIATION USED}

KSA: Kingdom of Saudi Arabia, MOH: Ministry of Health.

\section{REFERENCES}

1. Brenner TS, Godwin HN, Gouveia WA, Hodgkins BD, Kent SS, Kienle PC, et al. ASHP guidelines: Minimum standard for pharmacies in hospitals. Am J Heal Pharm. 2013;70(18):1619-30.

2. Pedersen CA, Schneider PJ, Scheckelhoff DJ. ASHP national survey of pharmacy practice in hospital settings: Prescribing and transcribing-2016. In: American Journal of Health-System Pharmacy. 2017;1336-52.

3. Pedersen C, Pharm, Schneider P, Scheckelhoff D, Pedersen. ASHP national survey of pharmacy practice in hospital settings: Prescribing and transcribing-2016. Am J Heal Syst Pharm. 2017;74:411-27.

4. Pedersen CA, Schneider PJ, Scheckelhoff DJ. ASHP national survey of pharmacy practice in hospital settings: Monitoring and patient education-2015. Am J Heal Pharm. 2016;73(17):1307-30.

5. Pedersen CA, Schneider PJ, Scheckelhoff DJ. ASHP national survey of pharmacy practice in hospital settings: Dispensing and administration - 2014. Am J Heal Pharm. 2015;72(13):1119-37.

6. Pedersen CA, Schneider PJ, Scheckelhoff DJ. ASHP national survey of pharmacy practice in hospital settings: Prescribing and transcribing - 2013. Am J Heal Pharm. 2014;71(11):924-42.

7. Pedersen CA, Schneider PJ, Santell JP, Kelly EJ. ASHP national survey of pharmacy practice in acute care settings: Monitoring, patient education, and wellness-2000. Am J Heal Pharm. 2000;57(23):2171-87.
8. Alsultan MS, Khurshid F, Salamah HJ, Mayet AY, Al-jedai AH. Hospital pharmacy practice in Saudi Arabia: Prescribing and transcribing in the Riyadh region. Saudi Pharm J. 2012;20(3):203-10.

9. Alsultan MS, Khurshid F, Mayet AY, Al-Jedai AH. Hospital pharmacy practice in Saudi Arabia: Dispensing and administration in the Riyadh region. Saudi Pharm J. 2012;20(4):307-15.

10. Alsultan MS, Mayet AY, Khurshid F, Al-jedai AH. Hospital pharmacy practice in Saudi Arabia: Drug monitoring and patient education in the Riyadh region. Saudi Pharm J. 2013;21(4):361-70.

11. CIBAHI. Medication Management. In: National Accreditation Standard [Internet]. 2nd Editio. Saudi Central Board for Accreditation of Healthcare Institutions.; 2016. Available from: http://insights.ovid.com/crossref? an $=01222928-201713010-00016$

12. The Joint Commission. 2016 Comprehensive Accreditation Manuals. Joint Commission Resources. 2016.

13. Alomi YA, Alghamdi SJ, Alattyh RA. Strategic Plan of General Administration of Pharmaceutical Care at Ministry of Health in Saudi Arabia 2012 - 2022. JPharm Pharm Scien. 2015;1(13):1-8.

14. Ahmed-Alomi Y, Pharm B, Clin Pharm M. A new Guidelines on Hospital Pharmacy Manpower in Saudi Arabia. J Pharm Pract Community Med [Internet]. 2016;2(22):30-1. Available from: http://dx.doi.org/10.5530.jppcm.2016.2.1.

15. Alomi YA, Kurdy L, Aljarad Z, Basudan H, Almekwar B. Patient satisfaction of pharmaceutical care of primary care centers at Ministry of Health in Saudi Arabia. J Pharm Pract Community Med [Internet]. 2016;2(3):79-87. Available from: http:// dx.doi.org/10.5530/jppcm.2016.3.4.

16. Alomi YA. National Pharmacist Competency System at Ministry of Health Hospitals in Saudi Arabia. J Pharmacol Clin Res Mini Rev J Pharmacol Clin Res. 2016;1(3):1-5.

17. Alomi YA. Pharmacy Patient's Bill of Rights in Saudi Arabia. UK J Pharm Biosci. 2016;4(2):65-9.

18. Saudi Ministry of Health. Health Statistical Year Book 2016. Saudi Ministry of Health; 2016.

Cite this article as: Alomi YA, Shorog E, Alshahrani A, Alasmary S, Alenazi H, Almutairi A, Almutairi M. National Survey of Pharmacy Practice at MOH Hospitals in Saudi Arabia 2016-2017: Pharmacy Management and Resource. J Pharm Pract Community Med. 2018;4(1s):S9-S16. 